\title{
ACRL's Fiftieth Anniversary: For Reflection, for Celebration, and for Anticipation
} Edward G. Holley

We want to link the past with the future, and the 100th anniversary of the College Library Section gives us an excellent opportunity for reflection, for celebration, and for anticipation of the next 100 years.-Martha A. Bowman, cochair, ACRL Fifth National Conference, Research Libraries in OCLC: A Quarterly, Autumn 1987.

\section{REFLECTION: \\ THE BIRTH OF COLLEGE \& RESEARCH LIBRARIES}

When A. Frederick Kuhlman edited the first issue of College \& Research Libraries (December 1939), he pronounced its aims in the authoritative manner that was his hallmark. CERL was to serve as the communications medium for the new ACRL, but the journal was to do much more than that. The quarterly was also to publish articles from convention speeches, to serve as a clearing-house for educational research, to bridge the gap between college administrators/faculties and librarians, to serve as a bridge with other agencies and learned societies, to review and abstract books of interest to ACRL members, to stimulate research on improving library service and publish the research results, and to "help develop the A.C.R.L. into a strong and mature professional organization."

Those were ambitious gaols, to say the least. But in retrospect it is amazing not only that Kuhlman's aims and goals have been achieved in the last fifty years, but also how similar those aims and goals are to the current ACRL Strategic Plan. ${ }^{2}$ Indeed, A. F. Kuhlman would probably be amazed, surely gratified, at how far academic librarians have come since the days when he did battle with ALA Executive Secretary Carl Milam (1920-48) and the ALA establishment. For Kuhlman and his colleagues were anything but reticent about ALA's neglect of matters that concerned academic librarians.

At the heart of the disagreement was the ALA headquarters staff's lack of understanding of the nature of higher education and the academic library's relationship to scholarship and learning. Academic librarians believed the way to success in the academic library was to be more like the faculty, interested in scholarship, concerned about teaching, and devoted to research and publication. In that effort CERL was to play a crucial role. As David Kaser, one of Kuhlman's successors as ed- 
itor (1963-69) later commented, "CERL was a periodical intended at once to be [ACRL's] news bulletin, scholarly journal, and its forum. ${ }^{\prime \prime 3}$ At various stages it served all three functions well. Today, after the spin-off of the news to College $\mathcal{E} R$ search Libraries News in 1966, CERL is primarily a scholarly journal, indeed often the most cited and highly rated among all the scholarly periodicals in the field of librarianship. ${ }_{4}$ But ACRL and CERL have been a long time reaching that eminent position.

\section{ACADEMIC LIBRARIANS AND ALA: THE ACRL BACKGROUND}

Despite the fact that college and university librarians had formed the first ALA section in 1889 , there is little doubt that public librarians dominated the association's leadership well into the second half of the twentieth century. True, the first three ALA presidents could be regarded as academic types: Justin Winsor (1876-85), who had been Boston public librarian for nine years before transferring his allegiance across the river to Harvard in 1877; William Frederick Poole (1885-87), whose strong commitment to the public library did not preclude historical scholarship; and Charles Ammi Cutter (1887-89), librarian at the Boston Athenaeum, whose "delicate and accurate scholarship" in his famous catalog was well recognized in the scholarly community. But it was chiefly to the rapidly expanding public libraries that the association looked for leadership during its first 100 years; it was public library concerns that occupied most of the association's attention.

Of course there were scholars who assumed the presidency of ALA during its first century, e.g., Reuben Gold Thwaites, William Warner Bishop, Louis Round Wilson, but their presence did not alter ALA priorities. As Wayne Wiegand has noted, there were 45 public librarians among the first 100 ALA presidents (1876-1986), outnumbering academic librarians 2.6 to 1 . $^{5}$

After World War I academic librarians expressed increasing disillusion with ALA's neglect. Criticism began to be voiced after William Warner Bishop's presidency (1918-19) and the failed ALA effort in 1919-20 to secure funds for massive improvement in library service. This "Enlarged Library Program" has been described by historian Dennis Thomison as ALA's short-lived experiment as a welfare organization. ${ }^{6}$

For the next two decades academic librarians' dissatisfaction grew until it finally culminated in the birth of ACRL in 1938.

\section{THE COLLEGE AND \\ REFERENCE LIBRARY SECTION}

From its beginning in 1889, the ALA College Library Section was mainly a small discussion group of academic library administrators. To accommodate reference librarians, the section changed its name to the College and Reference Library Section in 1897. However, though the section began electing officers early in the twentieth century, it remained small until 1923 when it adopted its first set of bylaws. Growth was rapid after that, from 90 members in 1923 to 800 members in 1928 , though membership declined after 1928. Still, throughout the twenties, the College and Reference Library Section had obviously begun to attract attention. Growth of the section doubtless reflected both the changes in American higher education and the growth of colleges and universities in the first quarter of the century. With larger enrollments came expanded libraries and more librarians.

\footnotetext{
"Many academic librarians-both behind the scenes and occasionally in public-began to argue for a stronger professional organization that would emphasize bibliographic and scholarly activity to meet their needs in serving an expanding higher education community."
}

The section's programs reflected perennial issues in academic librarianship: personnel and faculty status, teaching students the use of the library, standards, 
interlibrary loans, and on- and off-campus services. Though formal and informal discussion of these issues continued until 1938 (and indeed throughout ACRL's fifty-year history), many academic librarians-both behind the scenes and occasionally in public-began to argue for a stronger professional organization that would emphasize bibliographic and scholarly activity to meet their needs in serving an expanding higher education community.

In 1921 Ernest J. Reece and his library school students began a series of articles, "College Library News," in the Library Journal. The articles offered current information on personnel changes, publications, buildings, gifts, and appointments for the period covered. This series continued through the midforties. CERL began publishing the series in 1943 but dropped it in 1945.

Other events in the twenties promoted a sense of need for a stronger forum for academic librarians. George Works' book, College and University Library Problems (1927), the result of a survey financed by the Carnegie Corporation, drew attention to the status of academic libraries and had a tremendous impact on librarians and some university administrators.

The emergence of the Graduate Library School (GLS) at the University of Chicago, another major Carnegie venture, offered both hope and skepticism in the library community. GLS aimed to prepare leaders through a program of research at the $\mathrm{Ph} . \mathrm{D}$. level, and thus do for librarianship what Harvard had done for law and John Hopkins for medicine, to use Carnegie President Keppel's phrase.

The first significant open disagreement with ALA came from Frederick Telford's study of library staff classification and pay plans in the midtwenties. ALA had employed Telford to do for librarians what was already being done by the federal government for civil service workers: define jobs and establish pay scales. ${ }^{7}$ What happened was a not-so-subtle revolt of the academic librarians in ALA. They believed that Telford didn't understand academia (he didn't) and that a plan that might work well for public librarians would not work at all for academic librarians. Consequently a subcommittee was appointed, under the leadership of Charles Harvey Brown (1875-1960), to develop a supplementary plan for librarians in higher education. Charlie Brown, who would later defend a higher status for academic librarians in the "Library" section of the U.S. Bureau of Education's massive study of land grant colleges and universities (1930), went to work with typical zeal and developed a separate report-Budgets, Classification, and Compensation Plans for University and College Libraries (1929)adopted as a supplement to the Telford plan for public librarians.

By the late twenties the section began to consider its future seriously. High among its priorities were bibliographic tools and a publication that would address the specific needs of academic librarians. Thus began the short-lived College and Reference Library Yearbook (1929-31). The Yearbook was dropped after only three years, ostensibly because it didn't pay its way (probably a result of the Great Depression) but also because a suitable editor couldn't be found.

The Carnegie Corporation, responsible for GLS' emergence, also expanded its interest in academic libraries. ${ }^{8}$ The Corporation sponsored surveys, standards, book collections, and basic book lists by underwriting the Charles Shaw and Foster Mohrhardt predecessors to Books for $\mathrm{Col}$ lege Libraries. The corporation's efforts gave added emphasis to the ALA's neglect of such matters. These activities have been well covered in Neil Radford's book The Carnegie Corporation and the Development of American College Libraries, 1928-1941, ACRL Publications in Librarianship, no.44.

Partly in response to the unrest among academic librarians, especially their request for a college library specialist at headquarters (turned down for financial reasons), ALA established a College Library Advisory Board (CLAB) in 1931. Despite the board's membership of librarians from such notable institutions as Michigan (Bishop); Vassar (Borden); Iowa State (Charles Brown); and Penn State (Lewis), the board was not very effective, chiefly 
for financial reasons, according to Radford, but also because of lack of interest on the part of ALA headquarters staff, according to Blanche McCrum (1887-1969), Washington \& Lee University librarian, who found her services as chair of CLAB frustrated by headquarters.'

CLAB did not stop the growing discontent in the thirties as the Carnegie Corporation, chiefly influenced by Bishop at Michigan and Louis Round Wilson at GLS, invested not only in research and bibliographic compilations but also in grants for college library book collections.

In 1932 university library directors disbanded their recently formed Administrators Round Table in favor of a separate Association of Research Libraries where they could discuss problems of large libraries.

By the midthirties a number of leading academic librarians were pushing for a reorganization of ALA to reflect the diverse interests of the association through stronger subunits. In 1936 the section approved a committee under Brown's leadership to study reorganization. The $A C R L$ Organization Manual (1956) called the Brown committee's report of 1937 "the key document of ACRL history. "10 Acceptance of the report was to result not only in "a radical reorganization" of the section (Brown's phrase), renaming it the Association of College and Reference Libraries in 1938, but also in ACRL's becoming the first ALA division in 1940.

The restructured ALA emerged from implementation of the report of its Third Activities Committee, which Brown also headed immediately upon completion of his report on the College and Reference Library Section. Brown had served on the Second Activities Committee and subsequently was to be ALA president in $1940-41$, so he could see that his four years' work on ALA restructuring was neither neglected nor hindered by headquarters.

The ALA activities committees were an outgrowth of criticism leveled by that perennial gadfly and founder of the separate Special Libraries Association, John Cotton Dana. In 1919 Dana, in a stinging criticism, had said that the chief ALA problem was "the lack of brains on the part of the members." He followed that criticism with another letter in 1927 that was highly critical of ALA's efforts in library education. The result had been the first Activities Committee, which reported in 1930, and another activities committee that reported in 1934. Neither the first nor the second committees' recommendations had resulted in significant organizational change, however. The Third Activities Committee was different, though the results would not be apparent for a decade. The difference came from the political skills of Charles Harvey Brown and, subsequently, ACRL's 1945-46 president, Blanche Prichard McCrum.

While the Third Activities Committee's achievement was, in form, the "radical reorganization" that Brown intended, it never resulted in a federation-type organization that brought in separate library associations like SLA in an umbrella arrangement, as Brown desired. The reorganization did give major ALA units semiautonomous status, however, and, after ACRL's threatened secession in 1946, an executive secretary of its ownthe long-desired college library specialist at headquarters. ${ }^{11}$ Subsequently, despite the partial success of the Cresap, McCormick, and Paget management/organizational study in the midfifties, and the failure of ACRL President Ralph Ellsworth's second attempt at secession in the early sixties, ALA did move toward stronger divisions. ${ }^{12}$ Much later, after the turmoil of the late sixties and early seventies, realistic self-determination came only after the change in the ALA dues structure in 1974.

\section{LEADERSHIP: PRESIDENTS AND EXECUTIVE SECRETARIES}

The obvious leader for the new Association of College and Reference Libraries (the name was changed to Association of College and Research Libraries in 1957, when the reference librarians departed to form their own division) was Charles Harvey Brown. When Brown declined to be selected as ACRL's first president, it was not because he was reluctant to assume that responsibility. His reasons were clear: he wanted to see the recommenda- 
tions of the Third Activities Committee implemented, and he did not intend to leave that to chance. What he did was to convince Frank K. Walter to become the first ACRL president and thus assure continuation of the thrust that had already been established. Correspondence in the ALA archives and in Brown's other letters indicates well his manipulation of the process. He had conducted an exhaustive survey of the ALA membership, spoken and written extensively on ALA restructuring, and was confident that decentralization of ALA was desired by the membership as well as desirable for academic librarians. Fortunately for him (though fortune probably had little to do with it), Brown was elected ALA vice-president in 1939 and served as president in 1940-41. Thus he was in the enviable position of assuring that his reorganization plan was carried out. In J. Victor Baldridge's terms, Charlie Brown was truly a "Machiavellian change agent" for ALA and ACRL. ${ }^{14}$

In the intervening fifty years, ACRL has had some remarkable leaders. After the secession movement of 1946, led by Blanche McCrum and Ralph Ellsworth, there were frequent tensions between ACRL and ALA. Many members did not believe that ACRL could trust the parent ALA to do the right thing by its major division. The strongest of that group was undoubtedly Ralph Ellsworth, the only person to have served two terms as ACRL president (1951-52; 1961-62). A leader in the 1946 battle, Ellsworth was a frequent ALA critic. In an oft-quoted article, "Critique of Library Associations in America," in $\mathrm{Li}$ brary Quarterly (1961) on the eve of his second ACRL presidency, Ellsworth reiterated his criticisms of the organization. ${ }^{15}$ While recognizing the importance of ALA's battles for intellectual freedom, federal legislation, international relations, and the welfare of all librarians, he also thought the organization was too bureaucratic, too big, and too indifferent to specialized interests of academic, public, and special librarians. He argued once more for ALA as a workable federation of library associations.

In response to this critique, ALA Executive Director David Clift noted that
Ellsworth would soon have the opportunity to try to bend ALA to his will, because he would shortly be ACRL president again. Ellsworth himself did not think that would occur, and it didn't. ${ }^{16} \mathrm{His}$ dream of a separate ACRL and a federation of library associations was delayed another decade, until the ALA changed its dues structure, transcended the old arguments, and became, in fact if not in theory, a federation.

That old attitudes die slowly was clear to this author when he joined several persons to testify before the ALA Executive Board in support of ACRL's request to hold a second national conference. Talk of secession if the board declined to grant permission was again in the air on the night before the meeting-political naïveté. Few boards willingly confront a phalanx of distinguished representatives from their largest unit without giving them what they want. The ALA Executive Board usually backs down under strong protests from its smallest unit; there was no likelihood of turning down a request from its major division.

What kind of persons have led ACRL in the last fifty years? Among the leaders one should certainly include presidents and executive secretaries, but also those who have edited its journal, CERL. An examination of the leaders' backgrounds and interests is revealing (see appendix A for a list of ACRL presidents and executive secretaries/directors).

From the beginning, university librarians have been the most numerous among ACRL presidents. Starting with Frank K. Walter at the University of Minnesota and continuing through Joseph W. Boisse at the University of California-Santa Barbara, in 1988-89, they constitute a remarkably strong group of leaders-this despite the competition from ARL, which, it has often been said, drained ACRL of the real academic library leadership. Of course not all of these presidents came from ARL libraries, but many have-including a number of the most recent presidents.

Not surprising, in view of the fact that approximately fifty percent of the membership comes from university libraries, those institutions account for $\mathbf{3 5}$ of the $\mathbf{5 0}$ 
persons who have served as ACRL presidents. ${ }^{17}$ Eight came from college libraries, one from a community college library, two each from public libraries and other types of libraries, and two from library schools. Of the college librarians, three were from women's colleges. Most of the ACRL presidents have been library directors.

Five ACRL presidents have subsequently been elected ALA presidents, as has one ACRL executive director.

\section{WOMEN AND MINORITIES IN LEADERSHIP POSITIONS}

In a gender-conscious age, one should note that only sixteen of the presidents have been women, though six of those served in succession from 1982-1988.

Beverly Lynch, who became executive secretary in 1972, was the first woman to hold that office. Since that time all executive secretaries/directors (the title was changed to executive director in 1980-81) have been women.

For reasons not clear to this author, no woman has ever served as editor of College $\mathcal{E}$ Research Libraries nor has one ever served as editor of ACRL Publications in Librarianship. However, one should note that a number of gender studies indicate that women librarians have not been as active in publishing as men. Cline's study indicated that males accounted for an overwhelming 80 percent of the contributing authors and 73 percent of the cited authors in CERL during its first forty years. ${ }^{18}$

Two well-known reference librarians, Mabel L. Conat, Detroit Public Library, and Winifred Ver Nooy, University of Chicago (and the 1944-45 president who initiated the protest of 1945-46), have served as president. Female presidents from college libraries are Blanche McCrum (Wellesley); Eileen Thornton (Oberlin); Helen Brown (Wellesley); and Anne Edmonds (Mount Holyoke).

Two black persons have served as president: Joseph H. Reason of Howard University and the late Louise Giles from Macomb County Community College, Michigan.

\section{EXECUTIVE SECRETARIES/DIRECTORS}

One of the strong arguments for sepa- rate status had included the need of having a college library specialist at ALA headquarters. Many persons familiar with ALA's bureaucracy believe that ACRL has been especially fortunate, not only in the quality of persons serving as executive secretaries/directors but also in capable headquarters staff who did not stay too long, as did two ALA executive secretaries, Carl Milam and David Clift.

The first executive secretary, N. Orwin Rush, stayed only two years (1947-49). He was succeeded by "young Arthur Hamlin, fresh from the University of Pennsylvania," under those tenure new publications emerged, including the first ACRL monograph in hard cover, Charlie Brown's Scientific Serials (1956). Hamlin served for seven years (1949-56). Both Richard D. Harwell, 1957-61, and J. Donald Thomas, 1968-72 (the period of the revolting librarians), served four year terms. Mark Gormley, 1961-62, and Joseph Reason, 1962-63, were really interim executives. George Bailey, 1963-68, served five years as did Beverly Lynch, 1972-77.

The three women executives, Beverly Lynch; Julio Virgo, 1977-84; and JoAn Segal, 1984- , have served during a time of transition for ALA divisions and a period of extraordinary growth for ACRL. During their tenure the publications programs, standards and guidelines, policy and planning documents, continuing education programs, and the national conferences have either been initiated or expanded. The executives have also been effective in seeking and maintaining divisional relationships with other professional and scholarly associations in higher education, a matter often talked about but frequently overlooked in the face of more pressing concerns.

While terms of seven years or less may be a cause for congratulation, short terms are scarcely the chief reason for their success. Each person has brought a strong background in academia and has understood the aims and goals of academic librarians. Each has also been supported by strong presidents and vice presidents. Housed as they were at ALA headquarters, each executive also had to balance the unique ACRL interests against the inter- 
ests of ALA as a whole-often not an easy task. Nor was strengthening the ties between chapters and ACRL headquarters easy, since visits and speeches by staff and ACRL presidents are both necessary and time-consuming. By any objective standard leadership at headquarters has been excellent. One can only be amazed that so much good work is done by so few persons.

\section{"Kuhlman aimed for $C E R L$ to be both a communications medium and a vehicle for scholarship."}

\section{PUBLICATIONS AND THEIR EDITORS College \& Research Libraries}

Kuhlman aimed for CERL to be both a communications medium and a vehicle for scholarship. Initially, the journal did both, first under Kuhlman himself (1939-41), then under Carl M. White (1941-48), followed by the long-term editor Maurice F. Tauber (1948-62).

Begun as a quarterly, CERL became a bimonthly in 1956. Tauber's successors include a series of well-known librarians who worked steadily to improve the quality and scholarship of the articles: Richard B. Harwell, David Kaser, Richard M. Dougherty, Richard D. Johnson, C. James Schmidt, and Charles Martell. During the expansion of higher education in the sixties, ACRL approved a separate publication for the news section. ACRL News, later renamed College \& Research Libraries News was first published in March 1966. In its 22 years of existence CERL News has grown to an incredible 748 pages per year and now publishes opinion pieces and short research articles, as well as news, ads, and official ACRL information eleven times a year. Meanwhile, CERL, continues as a bimonthly of approximately 650 pages a year.

Gloria S. Cline, in evaluating CERL's first forty years, noted that the journal has been a leading library science periodical since it first appeared. ${ }^{19}$ She also reported that CERL's scholarliness improved over the period 1939-79 so that it compares very favorably with journals in other disci- plines, especially in numbers of references per article and in up-to-date citations. Positive changes have occurred in the quality of manuscripts accepted and cited, and also in adhering to other high standards of scholarly publishing.

But Cline found a weak core of productive authors: only 17 out of 4,000 cited authors appeared often enough to be considered an "author core." Of those, three of the most cited were also leading contributors to $C E R L$. Six who contributed ten or more articles during the forty-year period include the familiar names of Robert Downs, Keyes Metcalf, Robert Muller, Ralph Ellsworth, Ralph Shaw, and Maurice Tauber. Also, though there was increasing collaborative authorship (a notable factor in science publishing) in the seventies, the vast majority of articles during the period had no coauthors.

\section{Other ACRL Series}

Two other series came into being in the fifties.

The first was ACRL Monographs, designed, as Maurice Taubor had suggested, for papers either too long for CERL or too limited in interest for the journal. The first monograph (1952), a photo offset item that sold at $\$ .35$ was Joe W. Kraus "William Beer and the New Orleans Libraries, 1891-1927." Over the years the monograph editorial board, while highly selective in the titles chosen (only forty-five have appeared in thirty-six years), did include a number of collections of essays. Therefore, in the early seventies, the editorial board decided to change the title to ACRL Publications in Librarianship. While the series is ecletic, most of the titles have been well received by reviewers.

The second series, initiated under Lawrence S. Thompson's editorship, was the ACRL Microcard Series. Chiefly a collection of master's theses and papers from library schools, the microcard series lasted from 1953 to 1969, and served, according to Charles Hale, "as an outlet for aspiring young college librarians."

In 1980 the College Libraries Section began a new series called Clip Notes (College Library Information Packets), containing "data and sample documents from academic libraries to assist librarians 
in establishing or refining services and operations." Ten have now appeared. Like other ACRL series titles, CLIP Notes has been highly successful.

Another major contribution ACRL has made to academic library advancement is the publication of library statistics. NonAssociation of Research Libraries university statistics have been published every other year since 1978. ACRL has also published HEGIS data collected by the federal government in 1984 and 1986. The Association also collected and published statistics of some colleges and universities in an out-of-series mode in 1984 and 1986. The latter series will reportedly not be continued. In the decline of federal government publication of library statistics, ACRL's provision of accurate comparative statistical data has been welcome.

\section{Choice and Books for College Libraries}

Perhaps no publications have served a more useful function than Choice and Books for College Libraries. By the midsixties, when the Great Society programs were just beginning, ACRL had already been at work for five years on a review journal to help college librarians and faculty in their selection of the best books for college libraries. Access to a high quality faculty who could assist in the reviewing led to Choice's location in Middletown, Connecticut, near the Wesleyan University campus.

Thanks to a grant from the Council on Library Resources, the first issue of Choice: Books for College Libraries, appeared in March 1964. Under the editorship of Richard Gardner, Choice quickly earned a place of importance among the book reviewing media. Drawing upon the expertise of faculty for subject reviews and librarians for reference reviews, the magazine focused attention on authoritative evaluation of new titles for the expanding enrollments in colleges and universities. A recent article indicated that Choice reviewed more books per year (about 6,600 ) than any other publication. Especially popular was the spinoff Choice Opening Day Collection, a list of about 1,800 titles regarded by the ed- itors of Choice as essential in any new college library.

Soon after Choice began publication, ALA published a major bibliographical tool, Books for College Libraries (BCL). The current reviews of academic books published in Choice was foreseen as a complementary, supplemental service to a basic booklist. There had long been a desire for a successor to the Shaw and Mohrhardt lists. The establishment of new campuses in the University of California system had led to compilation of a basic list of titles under the editorship of Melvin J. Voigt and Joseph H. Treyz. This list of 53,000 titles became the basis for the first edition of $B C L$, published in 1967. ACRL and ALA Publishing collaborated on the next two editions, 1975 and 1988 . The latest edition, with understandable hyperbole, is advertised as "the most authoritative academic library collection development and evaluation tool available today." In a sixvolume format, as well as online and on magnetic tape, $B C L 3$ will likely be as popular and useful as its predecessors.

In this way ACRL has fulfilled one of its major purposes.

\section{STANDARDS AND GUIDELINES}

Important for academic librarians over the years has been the development of standards for college library collections and standards and guidelines for library personnel. Not surprisingly, standards and guidelines remain a major priority for ACRL's membership.

ACRL standards and guidelines have had a strong impact on higher education, despite the fact that regional accrediting agencies have not been willing to adopt the ACRL standards as their own. Nonetheless, accreditation visiting teams often take note of how a college has used such documents. Moreover, a number of higher education boards used the earlier "Standards for College Libraries," (1959) as a measuring device for improving their state-supported college libraries, just as they have used the 1975 standards, and no doubt will use the 1986 revision, for the same purpose. Board staffs routinely refer to the ACRL standards as the "ALA Stan- 
dards," which may deny ACRL the credit but is technically correct since ALA delegates to its divisions responsibility for standards in their individual areas of expertise. The 1975 Standards for College Libraries broadened evaluation to include staff and space as well as collections, and have had a salutary effect in encouraging states with weaker college libraries to upgrade their library resources and services.

The College Library Standards apply to those four-year colleges and universities with only modest work at the graduate level. There are also standards and guidelines for two-year colleges and for universities.

Although measuring the impact may be difficult, this author believes that both the standards and the various guidelines have resulted in significant progress for small colleges and medium-sized universities, but probably have had less success in large universities.

\section{"The battle to secure a vital role for the library in the teaching and re- search process is never ending."}

The standards and guidelines most difficult to develop and maintain have been those involving personnel. The long battle of academic librarians for faculty/academic status has, at best, been only moderately successful. The debate over faculty status in the fifties between Robert B. Downs, a firm believer, and some other university librarians (at best, skeptical), resulted in a collection of essays published as ACRL monograph no. 22, The Status of American College and University Librarians, in 1958. ACRL adopted the Downs approach of full faculty status as the ideal. However, convincing academic administrators to adopt even the halfway house of academic status was hard fought, while full faculty status with rank and titles has not been achieved in most research universities. Moreover, there has clearly been some retrogression in the late seventies and early eighties.
In 1975 ACRL published Faculty Status for Academic Libraries, a collection of policy statements and articles in defense of faculty status. A new edition, Academic Status: Statements and Resources, has just appeared in 1988. In the current climate of higher education one can predict that the battle for academic librarians to maintain their status and position on campus will continue. Unfortunately, their colleagues, especially administrative colleagues (sometimes even library directors), are often their worst enemies. As the above paragraphs indicate, the battle to secure a vital role for the library in the teaching and research process is never ending.

\section{CONFERENCES AND AWARDS}

Over the fifty-year period, the ACRL presentations at ALA conferences have attracted increasing numbers of registrants. In recent years the ACRL President's Program has suffered from the same problem of all similar organizations: how does one plan a program on a substantive topic that embraces everyone, from the neophyte from library school to the sophisticated and experienced professional? The answer is "with difficulty." The result has been to focus more attention on the program of ACRL's fourteen sections, but even there the large numbers can present a problem. Section programs generally result in good attendance because of their more specific topics. To communicate effectively with members, all except two sections have now begun newsletters and the other two are giving consideration to some form of publication.

Since the Rare Books and Manuscripts Section's preconference programs began in 1958 , the unit has attracted such interest that it has had to limit attendance. RBMS conference papers and symposia have often been published, adding significantly to the literature in this important area. Recognizing the growing importance of its Rare Books and Manuscripts Section in 1987, ACRL began publishing a new semiannual serial, Rare Books and Manuscripts Librarianship.

Preconference continuing education courses are now a regular part of ACRL's 
programs at ALA, as they are for a number of other ALA divisions. They have grown in popularity, as more and more members recognize their need for updating skills in the bibliographic instruction, management, and technology areas.

ACRL was the first division to conduct a national conference apart from the ALA conferences. The Boston conference, in 1978 , was designed for presentation and discussion of research and professional papers of high quality and no business sessions. With an attendance of over 2,600, the 1978 conference exceeded expectations. Subsequent conferences have been held in Minneapolis (1981), Seattle (1984), and Baltimore (1986). By all accounts the conferences have succeeded in presenting current issues and research results well, though research papers have been fewer than professional papers.

At the fortieth anniversary conference in 1978, ACRL, with support from the Baker \& Taylor Company, presented its first annual ACRL Academic or Research Librarian of the Year Award to two giants in the profession: Robert B. Downs and Keyes D. Metcalf. Two other pioneers, Henriette D. Avram and Frederick G. Kilgour, shared this honor in 1979 , but the following years have seen the award made to only one person.

In 1921 friends of Eunice Rockwood Oberly established a memorial award to honor the compiler of the best bibliography in the field of agriculture. ACRL now administers this biennial award, which technically might be called ACRL's oldest. However, the Academic or Research Librarian of the Year was ACRL's first major award.

\section{RECENT DEVELOPMENTS: PLANNING}

In 1982 ACRL established an Academic and Research Libraries Personnel Study Group to assess the division's current personnel programs and priorities. This group commissioned Allen B. Veaner to prepare a paper focusing on "working librarians, not chief administrators," in light of changes taking place in the academic libraries' environment. Veaner's paper, "1985 to 1995: The Next Decade in
Academic Librarianship," was published in the May and July 1985 issues of CERL, with comments by four librarians. ${ }^{20} \mathrm{His}$ observations on the types of knowledge, skills, abilities, and attitudes which academic librarians will need during the decade have led to considerable discussion, especially among library educators, and have contributed to ACRL's planning process.

Strategic planning the current buzzword in academia and the corporate world, has had its impact on ACRL. Planning for the decade began in 1981 when ACRL appointed an Ad Hoc Committee on an Activity Model for $1990 .^{21}$ Soon thereafter ACRL mission, goals, and objectives were adopted; afterwards an ACRL Strategic Planning Task Force was appointed to develop a strategic plan.

At the 1986 ALA Conference, the task force presented the results of its work to the ACRL Board of Directors, which adopted it. The plan's basis came from top priorities identified by the ACRL membership: publications, continuing education, standards and guidelines, alliance with other professional and scholarly associations, and chapters. ${ }^{22}$

The introductory mission statement reads well in the light of ACRL's history: "The mission of the Association of College and Research Libraries (ACRL) is to foster the profession of academic and research libraries to serve effectively the library and information needs of current and potential users."

Major goals for carrying out the plan are

1. To contribute to the total professional development of academic and research librarians,

2. To enhance the capability of academic and research libraries to serve the needs of users,

3. To promote and speak for the interests of academic and research librarianship, and

4. To promote study, research and publication relevant to academic and research librarianship.

(CERL News, January 1987).

One reads this summary report with a keen sense of appreciation for how well the task force accomplished its work. Not only has the task force outlined subgoals and strategies in clearly understood prose, but they have also analyzed the As- 
sociation's strengths and external environment in a commendable way. It is easy to concur with their own assessment, "We now have a clear sense of our mission, a strong set of goals for the next five years, specific objectives, and strategies for meeting them. ${ }^{\prime 23}$ The ACRL Board has also initiated procedures to review the plan annually.

Another heartening aspect of ACRL's recent activities is its leadership in ALA divisional planning. $A C R L$, with support from the ALA Goals Award, managed the first divisional leadership enhancement program in 1984. The association has continued to work closely with other divisions in hammering out a new operating agreement with ALA. The strategic plan points out the significance of ACRL's position within ALA "not only in the symbolic recognition of the importance of one association for all types of libraries and library activities, but also in dollars. ...." The willingness to improve relationships and to recognize those common goals of all librarians as well as carry out goals specific to types of libraries and library activities augurs well for ACRL's future.

"ACRL has led the way in divisional national conferences, in continuing education and in noteworthy publications."'

\section{ACRL TODAY: CELEBRATION}

The facts are clear. ACRL on its fiftieth anniversary is far and away the largest, the most effective, and most prosperous of the ALA divisions. Representing almost one-fourth of the total ALA membership, ACRL has led the way in divisional national conferences, in continuing education, and in noteworthy publications. Among the separate library/information associations in the country, only the Special Libraries Association has a larger membership, by a thousand or so members. A 1983 ALA Yearbook article noted that ACRL's membership placed it as the fifth largest library association in the world!
Organizationally, the ACRL of today reminds one of the ALA itself. ACRL is a complex organization with a strong programmatic thrust. There are now 14 sections, all with vigorous and active programs; 39 chapters; 17 discussion groups; 49 ACRL level committees plus numerous section and discussion group committees; an active publishing program that would do justice to any major professional association; and a continuing education program both at ALA conferences, among chapters, and in grant-funded conferences for improving the quality of humanities programs in libraries.

ACRL has a sound budget plan and a firm financial base. In 1988-89 there will be a headquarters staff of about ten FTE, and a general budget of $\$ 1.1$ million. At Middletown, Connecticut, Choice will have a staff of twenty and a budget of $\$ 1.4$ million. Reserve funds for major projects like new editions of the $B C L$ are approximately half a million dollars.

With a membership of 9,044 personal and 1,126 organizational members (as of August 31, 1988), ACRL is in a strong position to celebrate the accomplishments of its first fifty years.

\section{ACRL: ANTICIPATION}

From the above recital, one can certainly conclude that ACRL members have a firm foundation for "Building on the First Century." The fifth national conference in Cincinnati is an appropriate place to launch ACRL's next 100 years, as cochair Martha Bowman has noted. Looking at the current and proposed ACRL programs one would be hard put to argue that the division is precluded from doing anything it wants to do. The battle for autonomy in its own programs, with its own staff, budgets, and conferences, is over. In the unlikely event of a major challenge, any future ALA Executive Board would clearly be the loser and so would the library profession.

One can argue persuasively, as Charlie Brown, Blanche McCrum, Ralph Ellsworth, and other academic librarians did, that librarianship needs an umbrella organization for common concerns such as access to information, national legisla- 
tion/funding, intellectual freedom, public awareness, and personnel resources (the ALA Priorities). One can also argue, as they did, that library/information science needs separate units to serve specialized interests.

ACRL contributes substantially to all of the ALA priorities in its specialized context, the academic library/information center. One need only mention the ACRL Standards for College Libraries recognized unofficially, if not officially, by accrediting bodies and various higher education boards. ACRL publications are regarded as a contribution to the scholarly community, whether one is talking about the prestigious book selection journal, Choic, or the ACRL Publications in Librarianship Series, or the various publications of the Rare Books and Manuscripts Section. College \& Research $\mathrm{Li}$ braries has long been among the top research journals in the library/information science field.

ACRL could now become a separate association if it wished, but there is little incentive for it to do so. The future looks bright for the association's next hundred years. Charlie Brown, who used his political skills to secure a semiautonomous ACRL division under an umbrella ALA, and that small giant Blanche McCrum, whose "marching orders" sent her troops into the battle from which stems ACRL's current success, would both be proud.

\section{BIBLIOGRAPHICAL NOTE}

The sources used for this paper came from a variety of places which have not been cited unless there was some special reason to do so. There are numerous letters on the early ALA-ACRL controversies in the ALA Archives at the University of Illinois, especially in the folders for the College Library Advisory Board and for College and Research Libraries. The author has not examined these files for the period beyond 1948. The documentary record for the period after 1949 is extensive. That period also covers the time of the author's involvement with ALA-ACRL, and this essay necessarily reflects his own interpretation of the events from that perspective. Particularly helpful are issues of the two journals, $\mathrm{Col}$ lege \& Research Libraries and CERL News, as well as issues of the ALA Yearbook, 1976- . One should also not overlook the collection of CERL articles edited by Richard D. Johnson for the ALA Centennial, Libraries for Teaching, Libraries for $R e$ search: Essays for a Century. Chicago: American Library Assn., 1977. ACRL Publications in Librarianship, no. 39.

The definitive history of ACRL is yet to be written, but Charles Edward Hale's Indiana University dissertation, listed in the references, is a good starting place for basic data. Perhaps as ACRL looks ahead to its next hundred years, the board might consider encouraging research on a definitive history of the association.

\section{REFERENCES AND NOTES}

1. A. F. Kuhlman, "Introducing 'College \& Research Libraries,' " College \& Research Libraries 1:7-10 (Dec. 1939).

2. "ACRL's Strategic Plan: The Mission, Goals, and Objectives of the Association of College and Research Libraries," College \& Research Libraries News 48:21-25 (Jan. 1987).

3. David Kaser, "A Century of Academic Librarianship as Reflected in Its Literature," College \& Research Libraries," 37:123 (Mar. 1986).

4. Gloria S. Cline, "College \& Research Libraries: Its First Forty Years," College \& Research Libraries 43:208-32 (May 1982). An excellent study based on her doctoral dissertation.

5. Wayne A. Wiegand and Dorothy Steffens, "Members of the Club: A Look at One Hundred ALA Presidents," University of Illinois Graduate School of Library and Information Science Occasional Papers, no. 182 (Apr. 1988), 30p. The reason that there were only 100 presidents in the 110 -year period is that four persons served more than one term.

6. Dennis Thomison, A History of the American Library Association, 1876-1972 (Chicago: American Library Assn., 1978), p.72-83.

7. Richard Rubin, "A Critical Examination of the 1927 Proposed Classifications and Compensation Plan for Library Positions by the American Library Association," Library Quarterly 57:400-25 (Oct. 1987). 
8. Neil A. Radford, The Carnegie Corporation and the Development of American College Libraries, 1928-1941, ACRL Publications in Librarianship, no. 44 (Chicago: American Library Assn., 1984). 257p.

9. For example, see Blanche McCrum to Charles Harvey Brown, 9/14/35 and 1/21/36; Brown to McCrum, 9/16/35 and 1/16/36, ALA Archives, University of Illinois, College Library Advisory Board, 22/2/5, Box 1 .

10. Association of College and Reference Libraries, ACRL Organization Manual. (Chicago, American Library Assn., 1956), p.8.

11. These events are discussed at some length in Edward G. Holley, "Charles Harvey Brown," in Wayne A. Wiegand, ed., Leaders in American Academic Librarianship: 1925-1975, p.28-36, Beta Phi Mu Chapbook 16, distributed by American Library Association for Beta Phi Mu, 1983; and his "Mr. ACRL: Charles Harvey Brown (1875-1960)," Journal of Academic Librarianship 7:271-78 (Nov. 1981). See also Betty Ruth Kondayan, "Blanche Prichard McCrum: A Small Giant," Journal of Academic Librarianship 8:73 (May 1982), and her "Blanche Prichard McCrum," in Wiegand, p.201-3; Edward R. Johnson, "Ralph E. Ellsworth," in Wiegand, p.112-15; and Charles Edward Hale, "The Origin and Development of the Association of College and Research Libraries, 1889-1960" (Ph.D. diss., Indiana Univ., July 1976), p.155-66. Hale's dissertation is a valuable compilation of data on the association, its programs, and its organization for the period covered.

12. Thomison, p.195-203. See also Ralph Ellsworth, Ellsworth on Ellsworth. . . (Metuchen, N.J.: Scarecrow, 1980), p.123-29.

13. Edward G. Holley, "Federation: An Idea Whose Time Has Come?," Library Journal 99:335-38 (Feb. 1, 1974). Holley and Frank B. Sessa, "The New Personal Dues Proposal," American Libraries 5:257-58 (May 1974). For recent report, see ACRL Executive Committee, "ALA and Its Divisions: Relationships Past, Present, and Future," College \& Research Libraries News 48:318-320 (June 1987).

14. J. Victor Baldridge, "Rules for a Machiavellian Change Agent: Transforming the Entrenched Professional Organization," in J. Victor Baldridge and Terrence E. Deal, Managing Change in Educational Organizations: Sociological Perspectives, Strategies, and Case Studies (Berkely: McCutchan, 1975), p.378-88.

15. Ralph E. Ellsworth, "Critique of Library Associations in America," Library Quarterly, 31:382-95 (Oct. 1961); with a reply by David Clift, 395-400.

16. Ellsworth on Ellsworth. .., p.128.

17. Ralph Ellsworth served twice as ACRL president, and hence the number of presidents is fifty instead of fifty-one.

18. Cline, p.227.

19. Ibid., p.208-32.

20. Allen B. Veaner, " 1985 to 1995: The Next Decade in Academic Librarianship, Part 1," College \& Research Libraries 46:209-29 (May 1985); "1985-1995, Part II," 46:295-308 (July 1985) with "Reactions. ..," 46:309-19.

21. JoAn S. Segal, "The Association of College and Research Libraries: What It Can Do For Academic Libraries in the 80s," Show-Me Libraries 36:11-12 (Oct./Nov. 1984). The ACRL articles in the ALA Yearbook also provide information on the planning process.

22. "ACRL's Strategic Plan . ...," p.23.

23. Ibid., p.25.

\section{APPENDIX A. ACRL PRESIDENTS (BEGINNING 1938)*}

1938-1939 Frank K. Walter

1939-1940 Phineas L. Windsor

1940-1941 Robert B. Downs

1941-1942 Donald Coney

19.2-1943 Mabel L. Conat

1943-1944 Charles B. Shaw

1944-1945 Winifred Ver Nooy

1945-1946 Blanche Prichard McCrum

1946-1947 Errett Weir McDiarmid

1947-1948 William H. Carlson

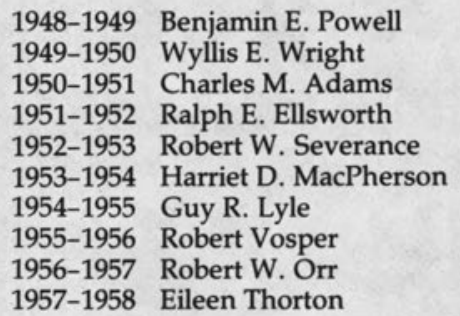

1948-1949 Benjamin E. Powell

1949-1950 Wyllis E. Wright

1950-1951 Charles M. Adams

1951-1952 Ralph E. Ellsworth

1952-1953 Robert W. Severance

1953-1954 Harriet D. MacPherson

1954-1955 Guy R. Lyle

1956-1957 Robert W. Orr

1957-1958 Eileen Thorton

^Formerly College Reference Section. Name changed by vote of section, June 1938. Approved by ALA Council, Dec. 1938. 
1958-1959 Lewis C. Branscomb 1959-1960 Wyman W. Parker 1960-1961 Edmon Low 1961-1962 Ralph E. Ellsworth 1962-1963 Katherine M. Stokes 1963-1964 Neal R. Harlow 1964-1965 Archie L. McNeal 1965-1966 Helen Margaret Brown 1966-1967 Ralph E. McCoy 1967-1968 James Humphrey III 1968-1969 David Kaser 1969-1970 Philip J. McNiff 1970-1971 Anne C. Edmonds 1971-1972 Joseph Reason 1972-1973 Russell Shank 1973-1974 Norman E. Tanis
1974-1975 H. William Axford

1975-1976 Louise Giles

1976-1977 Connie R. Dunlap

1977-1978 Eldred R. Smith

1978-1979 Evan I. Farber

1979-1980 Le Moyne W. Anderson

1980-1981 Millicent D. Abell

1981-1982 David C. Weber

1982-1983 Carla J. Stoffle

1983-1984 Joyce Ball

1984-1985 Sharon J. Rogers

1985-1986 Sharon Anne Hogan

1986-1987 Hannelore Rader

1987-1988 Joanne Euster

1988-1989 Joseph A. Boisse

\section{APPENDIX B. ACRL EXECUTIVE DIRECTORS}

1947-1949 N. Orwin Rush

1949-1956 Arthur T. Hamlin

1957-1961 Richard B. Harwell

1961-1962 Mark M. Gormley

1962-1963 Joseph H. Reason
1963-1968 George M. Bailey
1968-1972 J. Donald Thomas
1972-1977 Beverly P. Lynch
1977-1984 Julie A.C. Virgo
1984- JoAn S. Segal

\section{APPENDIX C. ACRL'S FOURTEEN SECTIONS}

Anthropology and Sociology Section (ANSS) Art Section (ARTS)

Asian and African Section (AAS)

Bilbiographic Instruction Section (BIS)

College Libraries Section (CLS)

Community and Junior College Libraries

Section (CJCLS)

Education and Behavioral Sciences Section (EBSS)
Law and Political Science Section (LPSS)

Rare Books and Manuscripts Section (RBMS)

Science and Technology Section (STS)

Slavic and East European Section (SEES)

University Libraries Section (ULS)

Western European Specialists Section (WESS)

Women's Studies Section (WSS) 